Arab World English Journal (AWEJ) Special Issue on Covid 19 Challenges April 2021

DOI: https://dx.doi.org/10.24093/awej/covid.2

\title{
Sheltered Instructional Observational Protocol Model in Digital Teaching EFL Students in Ukraine
}

\section{Anzhelika Solodka}

Department of German Philology and Translation, Faculty of Philology, V.O. Sukhomlynskyi National University of Mykolaiv,Ukraine Corresponding Author: a.solodkaya1967@gmail.com

\section{Svitlana Zaskaleta}

Department of English Language and Literature, Faculty of Philology, V.O. Sukhomlynskyi National University of Mykolaiv, Ukraine

\section{Tetiana Moroz}

Dean of Faculty of Philology,

V.O. Sukhomlynskyi National University of Mykolaiv, Ukraine

\section{Olha Demianenko}

Department of General and Applied Linguistics, Faculty of Philology, V.O. Sukhomlynskyi National University of Mykolaiv, Ukraine

Received: 3/5/2021

Accepted: 4/3/2021

Published: 4/26/2021

\section{Abstract}

Digital teaching has become an alternative way to replace the conventional learning process in COVID pandemic time. Educators explore different language achievement strategies to assist students on the way to academic success. One of the approaches the teachers can benefit from significantly is instructional modal - the Sheltered Instructional Observational Protocol (SIOP). This study aims to determine the effectiveness of SIOP instructional strategies in this digital teaching of EFL students. The study was conducted at the undergraduate level for English language learners in the Faculty of Philology, V.O. Sukhomlynskyi National University of Mykolaiv, Ukraine. The researchers conducted the study in the first semester of 2020. The contribution of this study is to evaluate experience of teachers in instructional strategies and to assess their effectiveness in digital teaching. The study analyzes the responses of twenty-five teachers and 63 students to the SIOP-based survey. A descriptive statistical method was used to test the validation. The results of the recearch show that EFL learners are not satisfied with activities to apply language and content knowledge. The results justified that teachers need to establish active online communication with their students. The study presents some recommendations for EFL teachers to improve their professional skills by adopting the specific components of SIOP and mastering their instructional strategies in digital learning. The implementation of the SIOP Model in digital teaching could bring appropriate and meaningful resources for high school teachers as a tool for them to grow professionally in COVID pandemic time.

Keywords: digital content teaching, instructional strategies, online teaching, Sheltered Instructional Observational Protocol modal, Sheltered Instructional Observational Protocol, Ukrainian EFL University students

Cite as: Solodka, A., Zaskaleta, S., Moroz, T., \& Demianenko, O. (2021). Sheltered Instructional Observational Protocol Model in Digital Teaching EFL Students in Ukraine. Arab World English Journal (AWEJ) Special Issue on Covid 19 Challenges (1) 21-36. DOI: https://dx.doi.org/10.24093/awej/covid.2 


\section{Arab World English Journal (AWEJ) Special Issue on Covid 19 Challenges April 2021}

Sheltered Instructional Observational Protocol Model

Solodka, Zaskaleta, Moroz \& Demianenko

\section{Introduction}

Implementation of digital technologies in the learning process started before the COVID19 pandemic. In the current Millennium Era, technology usage plays a vital role in supporting teaching and learning processes to make the content understandable. The use of digital content in the learning process is a very viable, alternative way to replace the conventional learning process (Alrubaie, Alrubaie, \& Hassoon, 2020).

Digital education during the COVID-19 lockdown showed some concerns about essential directions, which should be improved: curriculum, evaluation, academic planning and management, guidance and counseling, the use of edTechs. The spread of the virus has accelerated online learning in the world, particularly in Ukraine. Disasters will continue to occur, and technologies will help us cope with them (Andriivna, Vasylivna, Pavlivna, \& Smaglii, 2020).

Negative consequences COVID-19 is likely to have on education. The teachers' goal is to focus on one big positive change during this time: strengthening university-school-family blocks, figuring out how to effectively respond to support their students on their own. (Reich, Buttimer, Fang, Hillaire, Hirsch, Larke, \& Slama, 2020). The doors these partnerships and networks have opened may transform how teachers think about teaching and instruction by shifting into a new domain - the digital age of university-school blocks with an emphasis on trauma-informed and social-emotional learning (SEL) supports (Reich et al., 2020; Thomas, Crosby, \& Vanderhaar, 2019).

During this time, it is complicated to quantify to what degree students are engaging with content and understanding teacher's instructions on distance. The external conditions make it necessary to find new communication channels that allow us to implement the learning process in isolation (Rezvan, Ilienko, Zelinska, Krokhmal., \& Prykhodko, 2020). The main question is how to provide support for various instructional scenarios in digital learning and develop strategies to maneuver the additional stressors and challenges posed by teaching during COVID19 (Hodges, Kerch, \& Fowler, 2020). As instructors during the COVID-19 pandemic, teachers must constantly introduce new teaching methods to keep the students interested and motivated. During the COVID-19 pandemic, the motivation of stuents to learn is low because they only study at home. Therefore, the teachers should overcome this problem (Fansury, Januarty, Rahman, \& Syawal, 2020).

EFL teachers are searching the ways to lead their students to academic success. They face challenges in finding the tools to make the content of the subject understandable in digital learning. Sheltered Instruction Observation Protocol (SIOP) represents the instructional strategies making the content more accessible (Song, 2016).

Instructional strategies meet the needs of students and can significantly help them acquire the content of each lesson. The modal provides verified techniques for teachers through additional research to increasing their professionalism (Khong \& Saito, 2014; Song, 2016).

The researchers conducted the study with the belief that instructional strategies of SIOP can become an influential factor of the teaching process to foster interaction and communication. Understanding teacher's instructions by students can enhance the learning process. 


\section{Arab World English Journal (AWEJ) Special Issue on Covid 19 Challenges April 2021}

Sheltered Instructional Observational Protocol Model

Solodka, Zaskaleta, Moroz \& Demianenko

The contribution of this study is to evaluate the experience of teachers in instructional strategies and to assess their effectiveness in digital teaching. The goal of this research is to investigate the efficacy of SIOP strategies of online education in the Ukrainian university setting. The study had the following target questions: What SIOP techniques do Ukrainian teachers practice in digital education? How much are they productive in delivering lessons? Do students perceive their instructions? What kind of instructional strategies do teachers need to implement in their practice in e-learning? Do EFL students benefit from promoting e-learning?

The objectives of this research are as follows:

- Familiarize teachers and students with instructional strategies of the SIOP Model;

- Determine the correspondence of teaching techniques in e-learning to the SIOP Model and assess the effectiveness of EFL teachers;

- Explore possible solutions and recommendations for implementing the SIOP Modal that can facilitate teachers' professional development during pandemics.

\section{Literature Review}

\section{The characteristics of the Sheltered Instructional Observational Protocol}

Comprehending the content is a significant point for English language learners (ELLs). Different approaches suggest effective practices to make the instructions of teachers understandable (Calderon \& Zamora, 2011; Cervetti, Kulikowich \& Bravo, 2015; Genesee, Lindholm-Leary, Saunders, \& Christian, 2006; Pray \& Jiminez, 2009; Short, D. \& Himmel, 2013) state the importance of teachers' proficiency to assist linguistically and culturally different students.

The theoretical ground of this model is the statement that language acquisition means meaningful use and learning (Kareva \& Echevarria, 2013). Foreign language learning should include activities that integrate skills of listening, speaking, reading, and writing. The model implements the relationship between the language and content of the subject (Muhanna, 2019). Teachers consistently and regularly increase students' knowledge of the academic language as an integral part of professional activity (Lyster, 2017). The model takes into account the unique needs of students in language development. Teachers make the content understandable using modeling, tutoring, multicultural content, and native language (Cisco \& Pardon, 2012).

They create a particular environment where students feel comfortable experimenting with language. The environment includes settings when students learn a new language through content teaching and where the language of instructions is different from the native language of students. Teachers use a variety of proven instructional features, providing opportunities for practicing the target language.

They also establish specific links between the content of the subject, students' experiences, and prior knowledge, focusing on expanding vocabulary of students. This activity requires a high level of student involvement and interaction, leading to detailed discourse and higher-order thinking. Students master functional language skills, such as reconciling meanings, explaining, confirming information, arguing, persuading, and disagreeing. Through learning 


\section{Arab World English Journal (AWEJ) Special Issue on Covid 19 Challenges April 2021}

Sheltered Instructional Observational Protocol Model

Solodka, Zaskaleta, Moroz \& Demianenko

conversations and meaningful activities, students practice and apply their new knowledge of language and content.

For the past 20 years, SIOP has become a widely used approach for teaching in the USA. A dozen countries use it to teach content through non-native language of students. This model is empirically tested as a framework planning and delivering instructions as a framework for planning and delivering instructions in content areas for students who need to strengthen their academic language and literacy skills. Echevarria, Vogt, and Short (2004, 2008, 2010, 2013, 2017) described it in the main works. The model covers eight aspects of lesson design and delivery: lesson preparation, comprehensible input, strategies, interaction, practice and application, lesson delivery, review, and assessment (Short \& Himmel, 2013).

\section{Components of the modal}

The facilitation instruction model combines various teaching methods. Echevarria, Vogt, and Short (2017) described the components of the modal as following:

Lesson preparation includes objectives linked to standards and curricula. The goal is to assist students in gaining experience in progress toward fluency in academic English. Teachers meet students' expectations to know what they are going to learn and what they can do at the end of the lesson. Preparation includes providing adopted supplementary materials. Meaningful activities stimulate student interest in the subject and create the conditions to apply the knowledge.

Building Background connects new concepts with personal experiences of students and their past learning. It's necessary to activate prior knowledge to learn what they already know, to identify misinformation, or discover when it's essential for understanding. SIOP teachers increase attention to vocabulary instruction across the curriculum for effective reading writing, speaking, and listening.

Comprehensible input. EFLs acquire a new language differently. Teachers should use various appropriate language techniques (instructions fitting to student proficiency level, restatement, paraphrasing and repetition, previews and reviews important information) and additional accommodation techniques for students to comprehend the lessons' concepts (demonstrations, modeling tasks, gestures, pantomime, and movement). This activity demands the students' engagement into role plays, improvisations, simulations, experimental and discovery activities.

The next component includes Strategies: learning strategies, teacher-scaffold instructions, and higher-order thinking skills. Students should understand how to use learning strategies flexibly and benefit from combining them. The created tasks require the extended application of knowledge and represent complex thinking. By explicitly teaching cognitive and metacognitive learning strategies, teachers equip students for academic learning inside and outside the classroom. SIOP teachers capitalize on the learning strategies students already know and use in their mother tongue. 


\section{Arab World English Journal (AWEJ) Special Issue on Covid 19 Challenges April 2021}

Students learn the language through interaction that helps students develop and deepen content knowledge. In exchange, students practice essential language functions (asking for clarification, confirming interpretations, elaborating ideas, citing evidence to support claims, and evaluating opinions). It is a crucial aspect of educational achievement.

Practice and application create multiple modalities. SIOP teachers ensure that lessons include variouse activities that encourage students to apply both the content and language skills they are learning through means such as hands-on materials, group assignments, partner work, and projects.

Delivering lessons, teachers introduce meaningful activities to students; provide appropriate time for them to process concepts, foster motivation, and engagement. The main subject of Lesson Delivery is teaching support of the content and language objectives. It includes students' understanding of critical concepts as the goal.

Review and assessment are the necessary parts of the lesson to review the previous knowledge, check the topic knowledge, content, and language objectives. Review and assessment provide feedback, checking on student comprehension to determine whether additional explanations or re-teaching are needed.

The modal reflects many practices of teaching. Its adaptation accentuates attention to content during the professional development of EFL teachers.

\section{Digital learning systems}

Digital learning contributes quantitatively to teaching and learning interactions. The interaction on face to face learning is limited, that is, between instructors and learners only, but in digital learning, the learning interactions are more spread out. Interactions will occur between learners and learners, learners with instructors, learners with the environment, or learners with the media. The exchange may occur due to the support of digital media, such as e-learning, online discussion groups, e-mail, chat, instant messaging, streaming video, animation, Facebook, Instagram, and video conferencing. Digital content-based learning allows students to interact actively using computers or smartphones (Fansury et al., 2020).

Management of digital learning systems is different from conventional approaches. Digital learning systems require infrastructure and technology (technology support) (Fansury et al., 2020). Mobile technology creates new opportunities to improve the learning experience of students at all levels of education. It facilitates them to access educational resources in a new digital environment (Calimag, Mugel, Conde, \& Aquino, 2014).

Changing the learning system from conventional to e-learning during the COVID-19 pandemic has many challenges. It can provide new learning space and culture. By integrating social networks in teaching EFL students can take advantage of all the existing digital media to use them as learning instruments (Deng \& Tavares, 2013; Espinosa, 2015; Gorg, 2014).

Analyzing the tools, which educators use to promote virtual learning in the Algerian context, Ghounane (2020) admits that the most used tool for educational purposes is Facebook due to the motivation of students. The second one is the Moodle platform. 
Many educators think Google Classroom to be the most effective innovative teaching and learning online platform (Albashtawi \& Al Batainch, 2020). Al-Qahani. (2019), Hamouda (2020), Alahmadi, and Alraddadi (2020) proved the effectiveness of virtual classes for promoting interaction through the English language and enhancing communication skills. Learning styles and the technologies the students experienced is to evaluate if the learning style and the technologies complement each other (Syahrin \& Salih, 2020).

WhatsApp is one of the platforms that fits the needs of lecturers and students in conducting virtual classroom learning in times of pandemic (Asmara, 2020). Kelsen (2009), Brook (2011), Roodt and Peier (2013), Alwehaibi (2015) admit the affirmative impact of using YouTube in EFL classrooms on enhancing EFL content learning. Chen, Dobinson, and Kent (2020) consider that digital tools create a unique online learning environment that affects positively on learning. Students prefer the asynchronous environment to the synchronous one due to its flexibility (Al-Nofaie, 2020).

\section{Methodology}

The purpose of the research is to determine the correspondence of teaching techniques to the model. The study assesses the effectiveness of EFL teachers in digital teaching due to the COVID-19, and explores possible solutions and recommendations for future online learning.

\section{Method of data collection}

The researchers used a descriptive statistical method to test the validation of the study. The researchers created a five-point scale of assessment for each component, based on the Sheltered Instruction Observation Protocol (Echevarria et al., 2000).

\section{Participants}

The study was conducted at the undergraduate level for English language learners in Faculty of Philology, V.O. Sukhomlynskyi National University of Mykolaiv, Ukraine. The researchers conducted the study in the first semester of 2020. There were 88 participants in this study: Twenty-five EFL teachers and 63 undergraduate students in the Department of German Philology and Translation, and the Department of English Language and Literature. Most of the teachers had previous experience with digital teaching and did not have any experience with SIOP

\section{Research Instruments}

For conducting the study, the researchers created an online survey for teachers. The survey consists of three parts (Lesson Preparation, Instruction, Assessment) and 30 items.

Seeking authenticity in the naturalistic paradigm, the authors developed a code for each item to use in other informal or participant observations to allow the construction of data displays.

Teachers had to mark only one answer according to what they think best matches a digital teaching situation (e-learning): $0=$ Not observed; 1 = Poorly observed; $2=$ Somewhat observed; 3 = Observed; 4 = Highly observed. 
Arab World English Journal (AWEJ) Special Issue on Covid 19 Challenges April 2021

Sheltered Instructional Observational Protocol Model

Solodka, Zaskaleta, Moroz \& Demianenko

Table 1. The survey with the codes

\begin{tabular}{|c|c|c|}
\hline № & ITEM & CODE \\
\hline 1 & $\begin{array}{l}\text { You explain to students the content objectives of the lesson and what they will } \\
\text { be learning. }\end{array}$ & CONT OBJ \\
\hline 2 & $\begin{array}{l}\text { You give instructions to students about the objectives of the lesson, and they } \\
\text { will be learning in terms of grammar. }\end{array}$ & LANG OBJ \\
\hline 3 & $\begin{array}{l}\text { You use content appropriate to the age of students, English level, and } \\
\text { educational background. }\end{array}$ & CONTENT-AGE/EDU \\
\hline 4 & $\begin{array}{l}\text { You use digital supplementary materials regularly (besides the book) to make } \\
\text { lessons clearly and meaningful. }\end{array}$ & SUPP MAT \\
\hline 5 & $\begin{array}{l}\text { You adapt the content of your lesson to all English levels of your students' } \\
\text { proficiency. }\end{array}$ & ADAPT CONT \\
\hline 6 & $\begin{array}{l}\text { You use meaningful activities that integrate the lesson concepts with the } \\
\text { language practice for reading, writing, listening, and speaking. }\end{array}$ & MEAN ACT - RWLS \\
\hline 7 & $\begin{array}{l}\text { You typically relate the concepts of the lesson to background and experiences of } \\
\text { your students. }\end{array}$ & CONC-STU EXP \\
\hline 8 & You make explicit/obvious connections between past lessons and new concepts. & PASTL+NEWCON \\
\hline 9 & $\begin{array}{l}\text { You emphasize the vocabulary from the lesson by introducing it, highlighting it } \\
\text { for your students. }\end{array}$ & KEY VOC \\
\hline 10 & $\begin{array}{l}\text { You use speech appropriately for the English language proficiency level of your } \\
\text { students. }\end{array}$ & SPEECH \\
\hline 11 & You explain all academic tasks clearly. & CLEAR EXPL \\
\hline 12 & $\begin{array}{l}\text { You use various digital methods and techniques to make content concepts clear } \\
\text { (e.g., modeling, visuals, etc.). }\end{array}$ & TECHN \\
\hline 13 & $\begin{array}{l}\text { You provide a lot of opportunities for your students to use several digital } \\
\text { strategies to learn English. }\end{array}$ & SUPPORT-STRAT \\
\hline 14 & $\begin{array}{l}\text { You use scaffolding techniques (detailed explanations, slow speech rate, use of } \\
\text { visuals, etc.) during all the lesson to help and support your students understand } \\
\text { the content. }\end{array}$ & SCAFFOLD \\
\hline 15 & $\begin{array}{l}\text { You use many types of questions, but also those that promote higher-order } \\
\text { thinking skills to help your students understand the lesson. }\end{array}$ & QUESTIONS \\
\hline 16 & $\begin{array}{l}\text { You have interactions and discussions with all your students to understand the } \\
\text { lesson in virtual rooms better. }\end{array}$ & INTERACT/DISCUSS \\
\hline 17 & $\begin{array}{l}\text { You let your students work flexibly to support their learning of the language } \\
\text { and content objectives. }\end{array}$ & $\begin{array}{l}\text { GROUP } \rightarrow \text { LANG/CON } \\
\text { T OBJ }\end{array}$ \\
\hline 18 & $\begin{array}{l}\text { You wait enough time for your students to respond when they ask you a } \\
\text { question during the lesson. }\end{array}$ & WAIT TIME STU \\
\hline 19 & $\begin{array}{l}\text { You give your student several opportunities to clarify essential concepts in their } \\
\text { first language (Russian or Ukrainian) needed with the help of a helper. }\end{array}$ & L1 CLARIFY \\
\hline 20 & $\begin{array}{l}\text { You give your students the chance to use Internet recourses to practice, using } \\
\text { new content knowledge. }\end{array}$ & NEWCONT \\
\hline 21 & You give your students activities to apply the content and language knowledge. & APPLY LANG/CONT \\
\hline 22 & $\begin{array}{l}\text { You use activities that integrate all language skills: reading, writing, listening, } \\
\& \text { speaking. }\end{array}$ & LANG SKILL - RWLS \\
\hline 23 & The content objectives you use/teach well-supported by the lesson. & LESSON=CONT OBJ \\
\hline 24 & All students are engaged in the lesson, approximately $90 \%-100 \%$ & STU ENGAGED \\
\hline 25 & The speed of the lesson is appropriate to your students' ability level. & LESSON-PACING \\
\hline 26 & $\begin{array}{l}\text { You provide a comprehensible (detailed) review of the main vocabulary of the } \\
\text { lesson. }\end{array}$ & REVIEW KEY VOC \\
\hline 27 & You provide an understandable (detailed) review of the content concepts. & REVIEW KEY CONT \\
\hline 28 & You typically give feedback to all your student's response. & FEEDBACKS \\
\hline 29 & You assess your students' comprehension and learning of all lesson objectives & SCOMP \\
\hline
\end{tabular}


Arab World English Journal (AWEJ) Special Issue on Covid 19 Challenges April 2021

\begin{tabular}{|l|l|l|}
\hline & in class in e-learning. & \\
\hline 30 & $\begin{array}{l}\text { You evaluate student comprehension and learning of all lesson objectives } \\
\text { throughout the lesson. }\end{array}$ & $\begin{array}{l}\text { ASSESS } \\
\text { COMP/LEARN }\end{array}$ \\
\hline
\end{tabular}

Student Survey was parallel and identical in their criterion to teacher survey. Students had to evaluate their teachers in using instructions, methods, assessment, and lesson preparation. The researchers checked survey for validity and reliability fulfillment.

\section{Procedures}

Table 2. Time table of the research

\begin{tabular}{|c|c|c|}
\hline Dates of research & Stage & Participants \\
\hline $\begin{array}{l}\text { November } 2,2020 \\
\text { November } 4,2020 \\
\text { November } 6,2020\end{array}$ & $\begin{array}{l}\text { Stage } 1 \text {. Collecting the data of the } \\
\text { survey }\end{array}$ & $\begin{array}{l}\text { Teachers (9) } \\
\text { Teachers }(5) \\
\text { Teachers }(11)\end{array}$ \\
\hline $\begin{array}{l}\text { November } 9,2020 \\
\text { November } 10,2020 \\
\text { November } 11,2020 \\
\text { November } 12,2020\end{array}$ & $\begin{array}{l}\text { Stage 2. Collecting the data of the } \\
\text { survey }\end{array}$ & $\begin{array}{l}\text { Group } 1 \text { (18 students) } \\
\text { Group } 2 \text { (15 students) } \\
\text { Group } 3 \text { (16 students) } \\
\text { Group } 4 \text { (14 students) }\end{array}$ \\
\hline November 16-21, 2020 & Stage 3. Analysis of students survey & Researchers, observers \\
\hline November 23-27, 2020 & Stage 4. Analysis of teachers survey & Researchers, observers \\
\hline December 1-11, 2020 & $\begin{array}{l}\text { Stage 5. Analysis of correlation } \\
\text { between teachers observations in the } \\
\text { SIOP versus perceptions of students } \\
\text { on the survey }\end{array}$ & Researchers, observers \\
\hline December $14-23,2020$ & $\begin{array}{l}\text { Stage 6. Analysis of the scores of } \\
\text { teacher and student survey and SIOP } \\
\text { observation rating scale }\end{array}$ & Researchers, observers \\
\hline
\end{tabular}

\section{Results}

A calculation between the teachers' and students' mean scores are conducted to establish the dependency between the SIOP components. A mean score was found per each code (SIOP component) from both the teacher and students.

The interpretation given in the table below analyzes how teachers or students perceive that teachers are not meeting enough sheltered techniques in digital learning. The following table demonstrates the mean scores on each SIOP component (item) gained on the scale and the survey.

Table 3. The mean scores between the SIOP rating scale (teacher observations) and the mean scores of the SIOP survey (student observation)

\begin{tabular}{|l|l|l|l|l|}
\hline SIOP components (coded) & \multicolumn{3}{|l|}{$\begin{array}{l}\text { Teachers' Mean on the SIOP Rating } \\
\text { Scale }\end{array}$} & \multicolumn{2}{l|}{$\begin{array}{l}\text { Students' Mean on the SIOP } \\
\text { Survey }\end{array}$} \\
\hline CONT OBJ & 3.4 & Observed & 3,02 & Observed \\
\hline LANG OBJ & 2.7 & Observed & 3,4 & Observed \\
\hline SCONT-AGE/EDU & 3.7 & Highly observed & 3,38 & Observed \\
\hline SUPP MAT & 2.05 & Somewhat observed & 3,83 & Highly observed \\
\hline
\end{tabular}


Arab World English Journal (AWEJ) Special Issue on Covid 19 Challenges April 2021

\begin{tabular}{|l|l|l|l|l|}
\hline ADAPT CONT & 2.27 & Somewhat observed & 3,04 & Observed \\
\hline MEAN ACT(RWLS) & 2.6 & Observed & 2,74 & Observed \\
\hline CONC-STU EXP & 3.8 & Highly observed & 2,66 & Observed \\
\hline PASTL+NEWCON & 3.5 & Highly observed & 3,42 & Observed \\
\hline KEY VOC & 3.8 & Highly observed & 2,73 & Observed \\
\hline SPEECH & 3.8 & Highly observed & 3,45 & Observed \\
\hline CLEAR EXPL & 3.7 & Highly observed & 3,21 & Observed \\
\hline TECHN & 2.7 & Observed & 2,05 & Somewhat observed \\
\hline SUPPORT-STRAT & 3.0 & Observed & 3,01 & Observed \\
\hline SCAFFOLD & 2.6 & Observed & 2,59 & Observed \\
\hline QUESTIONS & 3.7 & Highly observed & 3,13 & Observed \\
\hline INTERACT/DISCUSS & 2.8 & Observed & 3,0 & Observed \\
\hline GROUP $\rightarrow$ LANG/CONT OBJ & 2.1 & Somewhat Observed & 2,54 & Observed \\
\hline WAIT TIME STU & 3.8 & Highly observed & 3,38 & Observed \\
\hline L1 CLARIFY & 3.4 & Highly observed & 3,45 & Observed \\
\hline NEWCONT & 2.1 & Somewhat observed & 2,29 & Somewhat observed \\
\hline APPLY LANG/CONT & 2.8 & Observed & 3,03 & Observed \\
\hline LANG SKILL(RWLS) & 3.7 & Highly observed & 3,43 & Observed \\
\hline LESSON=CONT OBJ & 3.1 & Observed & 2.96 & Observed \\
\hline STU ENGAGED & 3.0 & Observed & 3,08 & Observed \\
\hline LESSON-PACING & 3.1 & Observed & 2,99 & Observed \\
\hline REVIEW KEY VOC & 3.1 & Observed & 3,05 & Observed \\
\hline REVIEW KEY CONT & 3.5 & Observed & 3.04 & Observed \\
\hline FEEDBACK & 3.1 & Observed & 2,73 & Observed \\
\hline SCOMP & 2.9 & Observed & 3,22 & Observed \\
\hline SASSESS COMP/LEARN & 2.6 & Observed & 3,4 & Observed \\
\hline Total mean scores & $93.62 / 3.07$ & & $94.05 / 3.06$ & \\
\hline
\end{tabular}

The data shows a mismatch between the assessment of students and teachers. Students evaluated less the teachers in SCONT-AGE/EDU, CONC-STU EXP, KEY VOC, SPEECH, CLEAR EXP, QUESTIONS, WAIT TIME STU, LANG SKILL (RWLS), REVIEW KEY CONT, and FEEDBACK. Only in LANG OBJ, SUPP MAT, ADAPT CONT, APPLY LANG/CONT, and SCOMP the students evaluated their teacher higher. The SIOP observations mean scores show that the teachers don't apply much this component. Students under-evaluated their teachers in the mentioned categories. The graph reflects similar assumptions of means comparing SIOP results of students and teachers.

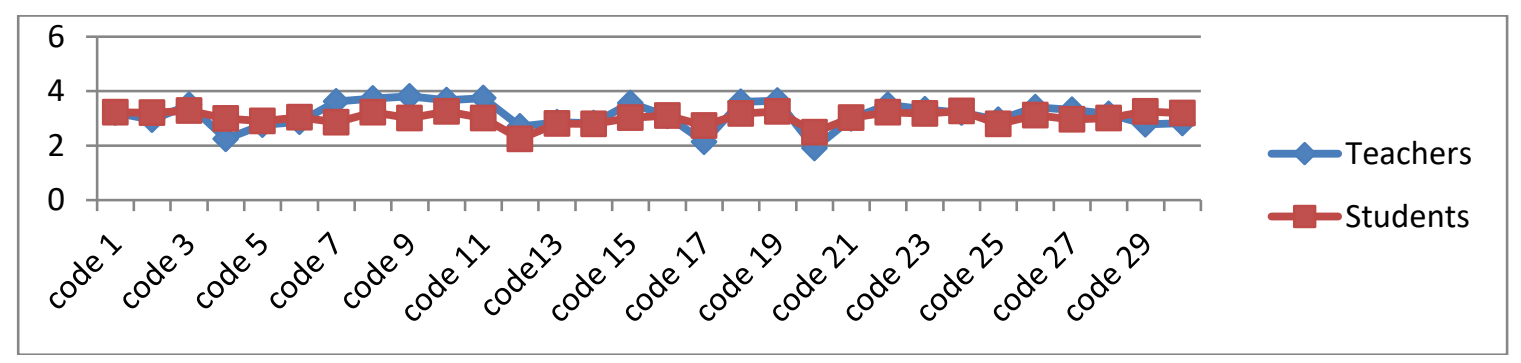

Figure 1. Correlation between Teachers Observations in the SIOP versus Perceptions of Students on the Survey 
The data reflects the correlated outcomes where the highest discrepancies were. There were significant gaps among most of the scores.

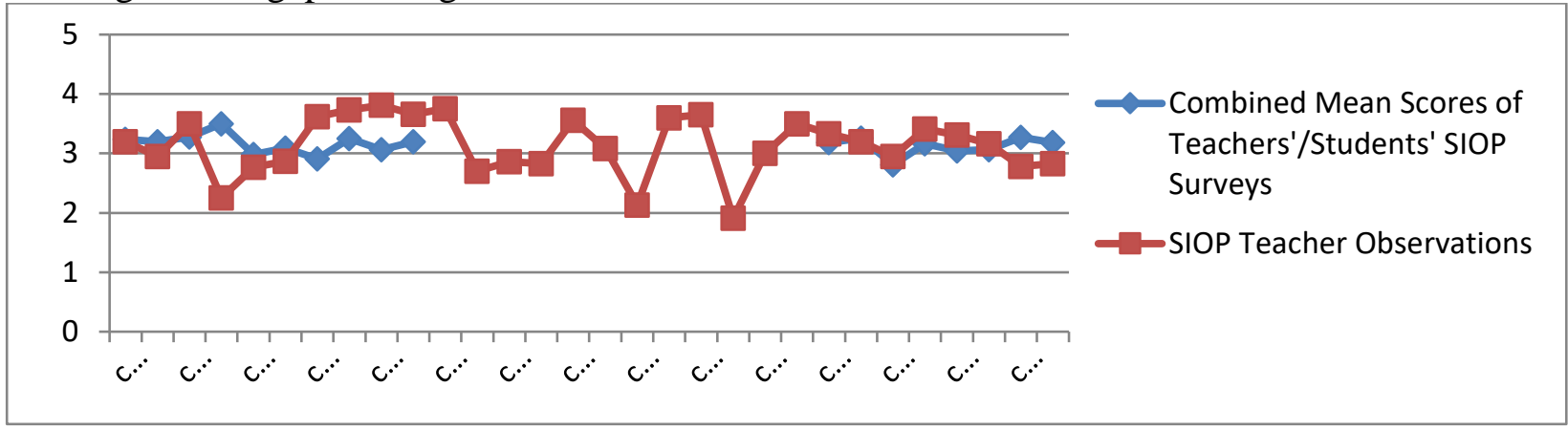

Figure 2. Combined Mean Scores of Teacher and Student Survey and SIOP Observation Rating Scale

The results show a mismatch between rate of students in components such as SCONTAGE/EDU, SUPP MAT, L1 CLARIFY, ADAPT CONT, CONC-STU EXP, PASTL+NEWCON, KEY VOC. Additionally, students assess less the teachers in clear explanations, grouping configurations, and time, students need to answer, clarification with native language, language tasks, and revising vocabulary. Only in the rate of SCAFFOLD, the students assessed the same as teachers did. The SIOP mean scores of observations demonstrate that the teachers apply some components. The mean score of teachers is 90.01 versus the students' mean score of students -60.32 . The research data revealed the most arguable SIOP categories: SCONT-AGE/EDU, CONC-STU EXP, KEY VOC, SPEECH, CLEAR EXP, QUESTIONS, WAIT TIME STU, LANG SKILL (RWLS), REVIEW KEY CONT, and FEEDBACK. The constructs that got the lowest marks (somewhat observed) were: TECHN, NEW CONT, SUPP MAT, ADAPT CONT.

The following SIOP categories were the most arguable: supplementary materials; essential vocabulary emphasized; concepts explicitly linked to background experiences of students; meaningful activities. The following constructs got the lowest marks (observing the graphs): usage of various techniques; group configurations support language and content objectives of the lesson; sample opportunities to use strategies; materials for students to practice using new content knowledge; activities to apply language and content knowledge. It is crucial to mention that teachers need to look at those components to develop appropriate strategies.

The data also demonstrated that 95, $6 \%$ of teachers use Moodle. Students prefer face-toface interaction in virtual classrooms (87\% of students) than working in Moodle. For this reason, Ukrainian IFL teachers integrated various applications such as Google Classroom, Zoom, Google Meet. The following data describes the online learning system in teaching English in Ukraine: $61.2 \%$ of teachers use Google Classroom, $23.5 \%$-Zoom, $15.3 \%$ - Google Meet.

\section{Discussion}

The study aimed to determine the effectiveness of SIOP instructional strategies in the digital teaching of EFL students. The responses of the survey indicate the positive attitude of students and teachers towards SIOP. 


\section{Arab World English Journal (AWEJ) Special Issue on Covid 19 Challenges April 2021}

The research and findings indicate that when teachers use the components of the SIOP Model in their classroom, they are more likely to help their students gain and retain information and vocabulary. As evidenced by the survey, many teachers apply the parts of the SIOP Model in their teaching. They explore the SIOP tools for lesson planning, self-monitoring, and reflection. This practice helps them to integrate language objectives into content lessons and the content into digital learning. Teachers admit they can be flexible to create their scaffolding instructions to foster interaction and communication.

This finding is consistent with that of Andriivna et al., 2020, who emphasizes that differentiated multilevel training provides cognitive motivation of students and stimulation of their mental activity; total assimilation of the primary component of the content of education; ongoing monitoring of learning material; introductory or final control for each unit of mastering educational material.

The teachers reported that the assessment of teaching effectiveness is crucial to the professional development of teachers. Using the rating scale of SIOP, teachers can identify areas for their professional growth and select one or two categories of SIOP as a professional goal for improvement. Well-designed lessons allow EFL students to practice the language and apply the information they study.

Thus, the findings of this research corroborate and support the findings of previous studies conducted by Echevarria et al., 2008, Short et al., 2013, in terms of using the rating scale to evaluate lessons, determining the correspondence of their teaching techniques to the SIOP Model.

The findings proved that SIOP is a ready-made designed program for teachers. The model helps teachers to organize well-thought-out lessons based on digital content and provides reflective practice for the teaching process.

These findings agree with those of Cisco et al., 2012, Khong (2014), and Song (2016), who noted that the model takes into account the unique needs of students in language development. EFL teachers make the content understandable, using modeling, tutoring, multicultural content, and native language.

The study showed that learners are motivated to use digital technologies in learning. They benefit from face-to-face interaction in Zoom and Google Classroom. This finding supports evidence from previous research conducted by Alahmadi et al., 2020, that virtual classroom has excellent potential in the EFL learners to overcome some learning obstacles.

The findings suggest that implementation of the SIOP model into digital teaching EFL students can facilitate professional development of teacher and meet the needs of students in acquiring the content of each lesson.

The study presents some recommendations:

- Exploring the goals of SIOP, teachers can distinguish effective strategies for EFL digital learning to support higher-level thinking that includes problem-solving and self-monitoring. 
Instructional strategies involve the students in scaffolding techniques that provide the support for them to move to the next level;

- Teachers can get experience in implementing SIOP. They explore student level of understanding through student engagement level, types of questions they ask, and their behavior. The visual clues help learners to understand the tasks. The analysis of individual student performance reveals the difficulties caused by the teacher;

- Changes in teaching do not take place easily and quickly. Teachers should follow achievement of their students' and understand their needs. This issue demands a significant amount of comprehensible input as well as curriculum modification. The process of practicing and perfecting SIOP is a matter of time and collaboration.

- The necessary steps are needed to facilitate SIOP training for teachers.

\section{Conclusion}

The study aimed to investigate the effectiveness of SIOP strategies in digital EFL teaching in the Ukrainian university context during COVID-19.

The study proved that implementation of the SIOP model could bring appropriate and meaningful resources for high school teachers as a tool for them to grow professionally in COVID pandemic time. The study showed promising significance for applying the SIOP-based instructional framework as means for digital teaching.

The results justified that teachers need to establish active online communication with their students to find their needs, abilities, and expectations. EFL teachers can improve their professional skills by adopting the specific components of SIOP and mastering their teaching strategies in digital learning.

As the result of this study, the research should continue to monitor the progress of students and the professional development of teachers in implementing SIOP strategies in digital teaching EFL students.

\section{About the Authors}

Anzhelika Solodka, Doctor of Science (Education), Professor of Department of German Philology and Translation at V.O. Sukhomlynskyi National University of Mykolaiv, Ukraine. Her main areas of interest include Cross-cultural Communication, Applied Linguistics and Translation. https://orcid.org/0000-0003-1703-7996

Svitlana Zaskaleta, Doctor of Science (Education), Professor of Department of English Language and Literature, at V.O. Sukhomlynskyi National University of Mykolaiv, Ukraine. Her main areas of interest include methods and practice of IFL Teaching. https://orcid.org/00000002-5417-2612

Tetiana Moroz, PhD (Education), Associate Professor, Dean of Faculty of Philology at V.O. Sukhomlynskyi National University of Mykolaiv, Ukraine. Main scientific interests: 
Arab World English Journal (AWEJ) Special Issue on Covid 19 Challenges April 2021

Sheltered Instructional Observational Protocol Model

Solodka, Zaskaleta, Moroz \& Demianenko

Theory and Practice of Translation, Cross-cultural Communication. https://orcid.org/0000-00022839-0739

Olha Demianenko, $\mathrm{PhD}$ (Education), Associate Professor of Department of General and Applied Linguistics at V.O. Sukhomlynskyi National University of Mykolaiv, Ukraine. Main areas of interest include Cross-cultural Communication, Language Teaching Methodologies. https://orcid.org/0000-0002-8937-3676

\section{References:}

Alahmadi, N.S. \& Alraddadi, B.M. (2020). The Impact of Virtual Classes on Second Language Interaction in the Saudi EFL Context: A Case Study of Saudi Undergraduate Students. Arab World English Journal (AWEJ), 11 (3), 56-72. DOI: https://dx. doi.org/ 10.24093 /awej/ vol11no3.4

Albashtawi, A. H., \& Al Batainch, K. B. (2020). The Effectiveness of Google Classroom among EFL Students in Jordan: An Innovative Teaching and Learning Online Platform. International Journal of Emerging Technologies in Learning (iJET), 15(11), 7888.

Al-Nofaie, H. (2020). Saudi University Students' Perceptions towards Virtual Education During Covid-19 Pandemic: A Case Study of Language Learning via Blackboard. Arab World English Journal, 11 (3), 4-20. DOI: https://dx.doi.org/10.24093/awej/vol11no3.1

Al-Qahani, M. H. (2019). Teachers' and Students' Perceptions of Virtual Classes and the Effectiveness of Virtual Classes in Enhancing Communication Skills. Arab World English Journal (AWEJ), Special Issue: The Dynamics of EFL in Saudi Arabia, 223-240. DOI: https://dx.doi.org/10.24093/awej/efl1.16

Alrubaie, S.A., Alrubaie, M.A., \& Hassoon, I.M. (2020). The Role of Activating Electronic Training in Increasing Efficiency of Training Process. Journal of Southwest Jiaotong University, 55 (1). Retrieved from http://jsju.org/index.php/journal/article/view/482.

Alwehaibi, H. O. (2015). The Impact of Using Youtube in EFL Classroom on Enhancing EFL Student' Content Learning. Journal of College Teaching and Learning-Second Quarter, $12(2), 121-126$.

Andriivna, B. O., Vasylivna, K. O., Pavlivna, K. O., \& Smaglii Valeriia Mykhaylivna, S. V. (2020). Using Distance EdTech for Remote Foreign Language Teaching During the COVID-19 Lockdown in Ukraine. Arab World English Journal: Special Issue on English in Ukrainian Context. 4-15. DOI: https://dx.doi.org/10.24093/awej/elt3.1 Retrieved from https://awej.org/category/englishlanguage-on-ukraine-context-2020/

Asmara, R. (2020). Teaching English in a Virtual Classroom Using WhatsApp during COVID19 Pandemic. Language and Education Journal, 5 (1), 16-27. Retrieved from http:// ejournal.uniski.ac.id/index.php/LEJ/article/view/152

Brook, J. (2011). The Affordances of YouTube for Language Learning and Teaching. Hawaii Pacific University TESOL Working Paper Series, 9 (1, 2), 37-56.

Calderon, C. T. \& Zamora, E. (2014). Factors Affecting the Implementation of Sheltered Instruction Observation Protocols for English Language Learners. National Forum of Educational Administration and Supervision Journal, 31, 20-31. Retrieve from https:// eric.ed.gov/?id =ED546989 
Arab World English Journal (AWEJ) Special Issue on Covid 19 Challenges April 2021

Calimag, J.N., Mugel, P.A., Conde, R.S., \& Aquino, L.B. (2014). Ubiquitous learning environment using the Andriod Mobile Application. International Journal of Research in Engineering \& Technology, 2 (2), 119-128.

Cervetti, G., Kulikowich J., \& Bravo, M. (2015). The Effects of Educative Curriculum Materials on Teachers' Use of Instructional Strategies for English Language Learners in Science, and Student Learning. Contemporary Educational Psychology, 40, 86-98. DOI: http://dx.doi. org/10.1016/j.cedpsych.2014.10.005

Chen, J., Dobinson, T., \& Kent, S. (2020). Students' Perspectives on the Impact of Blackboard Collaborate on Open University Australia (OUA) Online Learning. Journal of Educators Online, 17 (1). Retrieved from https://www.thejeo.com/archive/2020_17_1/chenchiang_ chendobinson_kent

Cisco, B. K. \& Padron, Y. (2012). Investigating Vocabulary and Reading Strategies with Middle Grades English Language Learners: A Research Synthesis. Research in Middle-Level Education Online, 36, (4), 1-23.

Deng, L., \& Tavares, N. J. (2013). From Moodle to Facebook: Exploring Students' Motivation and Experiences in Online Communities. Computer and Education, 69, 167-176. DOI: https: //doi.org/10.1016/j.compedu.2013. 04.028

Echevarria, J., Vogt, M., \& Short, D.J. (2004). Making Content Comprehensible for English Learners: The SIOP model (2nd ed.). Boston: Pearson.

Echevarria, J., Short, D., \& Vogt, M. E. (2008). Implementing the SIOP Model through effective Professional Development and Coaching. Boston, MA: Allyn \& Bacon.

Echevarria, J., Vogt, M. E., \& Short, D. (2010). The SIOP Model for Teaching Mathematics to English Learners. Boston: Allyn \& Bacon. Retrieve from https://www.colorincolorado.org/a rticle/language-objectives-keyeffective-contentareainstruction-english-learners

Echevarria, J., Vogt, M. E. \& Short, D. (2013). Making Content Comprehensible for English Learners: The SIOP Model (4 ${ }^{\text {th }}$ ed.). Boston: Allyn and Bacon.

Echevarria, J., Vogt, M. \& Short, D. (2017). Making Content Comprehensible for English Learners: The SIOP Model ( $5^{\text {th }}$ ed.). New York: Pearson.

Espinosa, L. F. (2015). The Use of Facebook for Educational Purposes in EFL Classrooms. Theory and Practice in Language Studies, 5(11), 2206-2211. DOI: http://dx.doi.org/10.17507/ tpls.0511.03 Retrieve from http://www.academypublication. com/ojs/index.php/tpls/article/ vie w/tpls051122062211

Fansury, A. H., Januarty, R., Rahman, A. W., \& Syawal. (2020). Digital Content for Millenial Generations: Teaching the English Foreign Language Learner on COVID-19 Pandemic. Journal of Southwest Jiaotong University, 55(3), 1-12. DOI: https://doi.org/ 10.35741/issn.0258-2724.55.3.40

Fewkes, A., \& McCabe, M. (2012). Facebook: Learning Tool or Distraction. Journal of Digital Learning in Teacher Education, 28(3), 92-98. Retrieved from http://www.academy publi cati on.c om/ojs/index.php/tpls/article/view/tpls051122062211

Genesee, F., Lindholm-Leary, K., Saunders, B., \& Christian, D. (2006). Educating English language learners: A synthesis of research evidence. New York, NY: Cambridge University Press.

Ghouname, N. (2020). Moodle or Social Networks: What Alternative Refuge is Appropriate to Algerian EFL Students to Learn during Covid-19 Pandemic. Arab World English Journal, 11 (3) 21-41. DOI: https://dx.doi.org/10.24093/awej 
Arab World English Journal (AWEJ) Special Issue on Covid 19 Challenges April 2021

Gorg, M. (2014). The Social Classroom: Integrating Social Network Use in Education. USA: IGI Global.

Hamouda, A. (2020). The Effect of Virtual Cases on Saudi EFL Students' Speaking Skills. International Journal of Linguistics, Literature and Translation, 3(4), 174-204. DOI: https://doi.org/10.32996/ijllt.2020.3.4.18

Hodges, T.S., Kerch, C., \& Fowler, V. (2020) Teacher Education in the Time of COVID-19: Creating Digital Networks as University-School-Family Partnerships. Middle Grades Review, 6 (2).

Kareva, V. \& Echevarria J. (2013). Using the SIOP Model for Effective Content Teaching with Second and Foreign Language Learners. Journal of Education and Training Studies, 1 (2), 239-248. doi:10.11114/jets.v1i2.173

Kelsen, B. (2009). Teaching EFL to the iGeneration: A Survey of Using YouTube as Supplementary. Material with College EFL Students in Taiwan. CALL-EJ Online, 10(2). Retrieved from http://callej.org/journal/10-2/kelsen.html

Kent, S. (2020). Students' Perspectives on the Impact of Blackboard Collaborate on Open University Australia (OUA). Online Learning. Journal of Educators Online,17 (1). Retrieve from https://espace.curtin.edu.au/hand le/20.500.11937/77825

Khong, T., D. H.K. \& Saito, E. (2014). Challenges Confronting Teachers of English Language Learners. Educational Review, 66 (2), 210-225. http://dx.doi.org/10.1080/ 00131911 .2013 .769425

Lyster, R. (2017). Content-Based Language Teaching. In S. Loewen \& M. Sato (Eds.), The Routledge Handbook of Instructed Second Language Acquisition (pp. 87-107). New York, NY: Taylor Francis.

Muhanna, B. (2019). Using SIOP Model to Engage Students and Promote Academic Knowledge of English Learners (ELS). In J. Keengwe, G., \& Onchwari, (eds.), Handbook of Research on Assessment Practices and Pedagogical Models for Immigrant Students (pp. 367-395). IGI Global. Retrieve from https://www.igiglobal.com/chapter/using-siopmodel-to-engagestudents andpromote-academic-knowledgeof-english-learners-els/229415

Pray, L., \& Jiminez, R. T. (2009). Literacy and English Language Learners: What Researchers and Policymakers Should Know. Educational Researcher, 38(5), 380-385. http://dx.doi.org/10.3102/0013189X09339353

Reich, J., et al. (2020). Remote Learning Guidance from State Education Agencies during the COVID-19 Pandemic: A first look. http://doi.org.10.35542/osf.io/437e2. Retrieve from https://scholarworks.uvm.edu/cgi/viewcontent.cgi?article $=1164 \&$ context=mgreview

Rezvan, O.O., Olna L. Ilienko, O.L., Zelinska, O,I., Krokhmal, A.M., \& Prykhodko, A.M. (2020). Digital Narrative as A Method of Emergency Distance Learning. Arab World English Journal: Special Issue on English in Ukrainian Context. 113-123. DOI https://dx.doi.org/10.24093/awej/elt3. Retrieve from https://awej.org/igital-narrativeas-amethod-of-emergencydistance-learning/

Roodt, S., \& Peier, D. (2013). Using YouTube in the Classroom for the Net-generation of Students. Issues in Informing Science and Information Technology, 10, 475- 488.

Ruben, A., (2014). Influence Of SIOP Cognitive Coaching Workshops On Teaching Practices Of ESL Teachers And ESL Paraprofessionals, (Unpublished Doctoral Dissertation). Wayne State University. Retrieved from https://core.ac.uk/download/ pdf/56686464.pdf 
Short, D. \& Himmel, J., (2013). Moving research on Sheltered Instruction into curriculum and professional development practice. Paper presented at American Educational Research Association (AERA) Annual Meeting, San Francisco, CA.

Song, K.H. (2016). Applying an SIOP-Based Instructional Framework for Professional Development in Korea. TESL-EJ Teaching English as a Foreign Language. The Electronic Journal for English as a Second Language, 20 (1). Retrieved from http://www.teslej.org/wordpress/issues/volume20/ej77/ej77a3/

Syahrin, S., \& Salih, A. A. (2020). An ESL Online Classroom Experience in Oman during Covid-19. Arab World English Journal, $11 \quad$ (3), $42-55$.DOI: https://dx.doi.org/10.24093/awej/ vol11 no3.3

Thomas, M. S., Crosby, S., \& Vanderhaar, J. (2019). Trauma-informed Practices in Schools Across Two Decades: An Interdisciplinary Review of Research. Review of Research in Education, 43(1), 422-452. DOI:https://doi.org/10.3102/0091732X18821123 